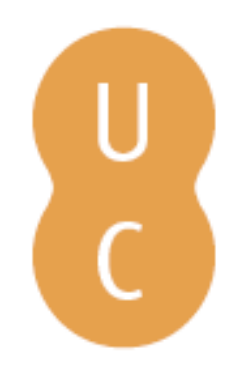

\title{
pommalina
}

\section{Sensor grid for fine particles monitoring during a fire: implications to firefighter's safety}

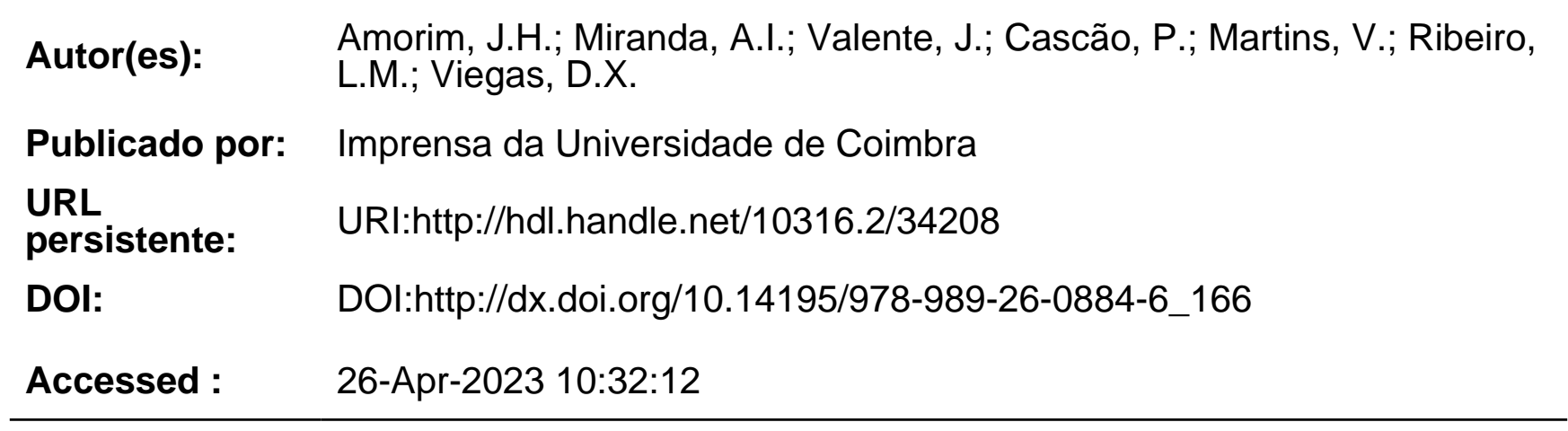

A navegação consulta e descarregamento dos títulos inseridos nas Bibliotecas Digitais UC Digitalis, UC Pombalina e UC Impactum, pressupõem a aceitação plena e sem reservas dos Termos e Condições de Uso destas Bibliotecas Digitais, disponíveis em https://digitalis.uc.pt/pt-pt/termos.

Conforme exposto nos referidos Termos e Condições de Uso, o descarregamento de títulos de acesso restrito requer uma licença válida de autorização devendo o utilizador aceder ao(s) documento(s) a partir de um endereço de IP da instituição detentora da supramencionada licença.

Ao utilizador é apenas permitido o descarregamento para uso pessoal, pelo que o emprego do(s) título(s) descarregado(s) para outro fim, designadamente comercial, carece de autorização do respetivo autor ou editor da obra.

Na medida em que todas as obras da UC Digitalis se encontram protegidas pelo Código do Direito de Autor e Direitos Conexos e demais legislação aplicável, toda a cópia, parcial ou total, deste documento, nos casos em que é legalmente admitida, deverá conter ou fazer-se acompanhar por este aviso.

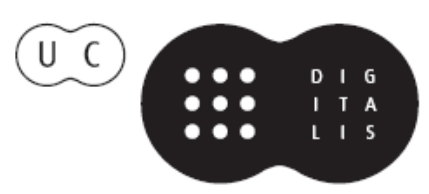




\section{ADVANCES IN}

Forest Fire

\section{RESEARCH}

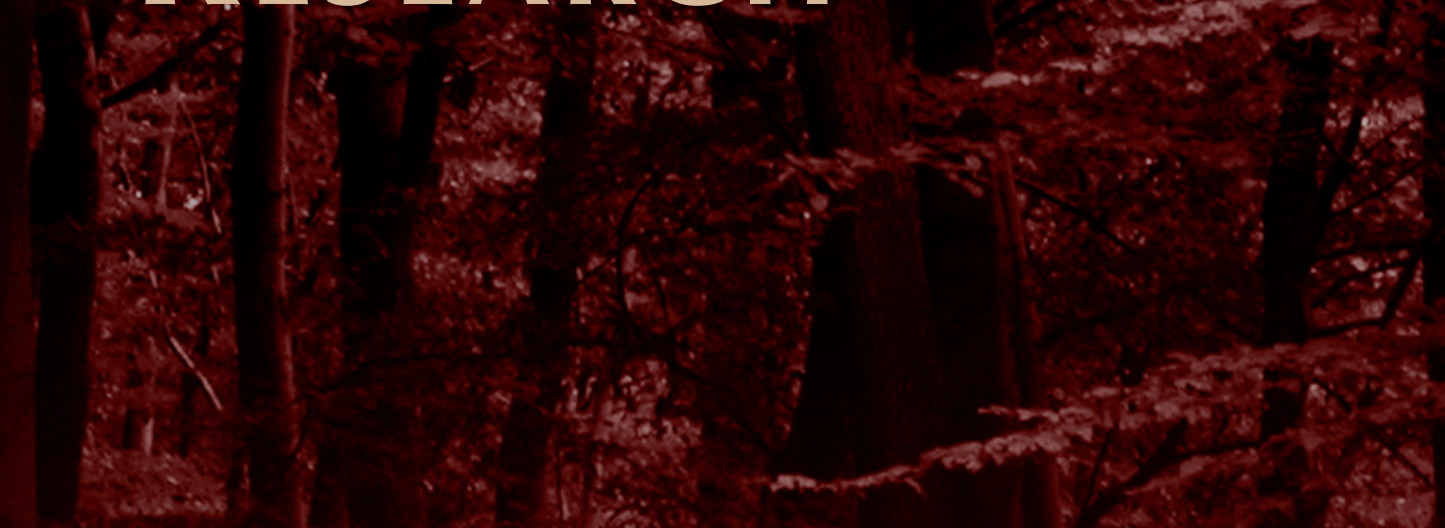

\section{DOMINGOS XAVIER VIEGAS}

\section{EDITOR}




\title{
Sensor grid for fine particles monitoring during a fire: implications to firefighter's safety
}

\author{
J.H. Amorimª, A.I. Miranda ${ }^{a}$, J. Valente ${ }^{a}$, P. Cascão ${ }^{b}$, V. Martinss ${ }^{a}$, L.M. Ribeiro ${ }^{c}$, and D.X. Viegas ${ }^{c}$ \\ ${ }^{a}$ CESAM \& Department of Environment and Planning, University of Aveiro, 3810-193 Aveiro, \\ Portugal,amorim@ua.pt, miranda@ua.pt, joanavalente@ua.pt, veram@ua.pt \\ ${ }^{b}$ Ecotech Pty Ltd, Knoxfield, Vic.3180 Australia, pedro.cascao@ecotech.com \\ ${ }^{c}$ Association for the Development of Industrial Aerodynamics, University of Coimbra, 3031-601 \\ Coimbra,Portugal, luis.mario@adai.pt, xavier.viegas@dem.uc.pt
}

\begin{abstract}
Forest fires are a massive source of air pollutants to the atmosphere causing several environmental and human impacts. It is generally accepted that firefighters are potentially exposed to critical levels of air pollution during fire suppression activities (both in direct combat and mop-up), but the concentrations attained in these areas are still scarcely quantified because of the difficulty inherent to the monitoring of air quality close to the fireline. The goal of this work is to provide a better understanding of the spatiotemporal dynamics of the smoke plume, and resulting levels of fine particles, in the proximity of a fire, and how this translates into human safety issues. The experimental study area is located in the mountain range of Lousã, Central Portugal. Ten in-continuum monitoring sensors were positioned at a distance of $5 \mathrm{~m}$ ( 8 sensors) and $10 \mathrm{~m}$ ( 2 sensors) from the top boundary of the burn plot, and at $1.7 \mathrm{~m}$ above ground. The concentration of particulate matter with an equivalent aerodynamic diameter smaller than $2.5 \mu \mathrm{m}$ (PM2.5) was measured during a total period of 50 minutes, capturing the effect of both flaming and smouldering emissions.

The results presented in this work highlight the fact that the concentration of fine particles in the atmosphere close to the fireline is extremely dynamic, with differences between sensors that go up to $540 \%$ in terms of average concentrations and $170 \%$ in peak values. This is particularly relevant taking into account that these values correspond to sensors at a distance of $10 \mathrm{~m}$. This conclusion suggests that in a single fire crew considerable differences in the exposure of its members can occur depending on their task/position relating the fireline.

For this particular burning plot the time evolution of the observations reveals a dip in PM2.5 concentration that is not explained by the analysis of smoke plume dynamics in video recordings, suggesting that under certain circumstances the visual estimate of fire safety conditions can be misleading due to e.g. reduced visibility. In wildfire suppression operations the safety of the involved personnel should rely also in the use of personal exposure monitoring equipment for the prevention of potentially critical exposure.
\end{abstract}

Keywords: real scale fire experiments; smoke emissions; fire safety; smoke exposure.

\section{Introduction}

Forest fires are a massive source of air pollutants to the atmosphere causing several environmental and human impacts. At the operational level, firefighters are confronted with extremely severe environmental conditions, including reduced visibility and toxic atmosphere. In this context, particulate matter, which is abundantly produced during forest fires, has significant effects over the safety and health of personnel in the terrain (e.g., Reinhardt and Ottmar [2004] and Miranda et al. [2010, 2012]). In fact, the International Agency for Research on Cancer (IARC) stated that the occupational exposure of a firefighter is possibly carcinogenic [IARC, 2010a]. There are a number of factors that affect the impacts of smoke on firefighter's health, including the concentration of specific air pollutants within the breathing zone, the exposure duration, the exertion levels, and the individual susceptibility (e.g., pre-existing lung or heart diseases) [Reisen and Brown, 2009]. In what relates specifically to smoke particles, the associated health effects not only depend on the chemical and toxic 
characteristics but also on their morphological properties, such as size, shape and density [Dost, 1991; Schwela, 2001; Naeher et al., 2007].

Despite the research studies carried out in the United States of America [Reinhardt et al., 2000; Reinhardt and Ottmar, 2000 and 2004], Australia [McMahon and Bush, 1992; Materna et al., 1993; Reisen and Brown, 2009; Reisen et al., 2011] and Portugal [Miranda et al., 2010 and 2012], the current state of knowledge in this field is still scarce. The difficulty inherent to the monitoring of air quality and personal exposure levels during a fire has largely contributed to this scientific gap.

The complex mixture of smoke constituents induces adverse health effects such as acute and instantaneous eye and respiratory irritation and shortness of breath, that can potentially develop into headache, dizziness and nausea lasting for hours, and mild impairment of lung function for hours to days [Reinhardt et al., 2000], while long-term effects are characterized by impaired respiratory function, increased risk of cancer, and cardiovascular disease [Rothman et al., 1991]. Special concern is raised by the exposure to respirable particles and potentially toxic compounds adsorbed to them, such as polycyclic aromatic hydrocarbons (PAHs) and semivolatile organic compounds, some of which may be carcinogenic [Le Masters et al. 2006; Youakim, 2006; IARC, 2010b].

Aiming to establish cause/effect relationships between exposure to smoke and firefighter's health effects it is fundamental to improve the current understanding about the spatial and temporal dynamics of air pollution levels close to the fireline. It is widely known that the composition of smoke depends on several factors, namely the type of vegetation consumed, the efficiency of combustion, the fuel moisture content, the fire temperature, and the weather conditions [Reisen and Brown, 2009]. However, the extent of the impact of smoke plume dynamics on individual exposure is scarcely documented by field observations. The main goal of this work is to evaluate the spatial and temporal variation of fine particles concentration during a bushfire, and how this potentially translates into human safety issues during firefighting operations.

\section{Fire experiments description}

The experimental study area is located in the mountain range of Lousã, Central Portugal $\left(40^{\circ} 15^{\prime} \mathrm{N}, 8^{\circ}\right.$ $10^{\prime} \mathrm{W}$ ), at an elevation of approximately $1,000 \mathrm{~m}$. The fire experiments described in this paper were carried out in May 6, 2010. The characteristics of the burn plot are described in Table 1.

Table 1. Physical characteristics of the burn plot. Fuel moisture was sampled 40 min before the fire ignition.

\begin{tabular}{ccccccc}
\hline $\begin{array}{c}\text { Area } \\
\left(\mathrm{m}^{2}\right)\end{array}$ & $\begin{array}{c}\text { Avg. } \\
\text { slope } \\
\left({ }^{\circ}\right)\end{array}$ & $\begin{array}{c}\text { Fuel cover } \\
(\%)\end{array}$ & $\begin{array}{c}\text { Avg. fuel } \\
\text { height } \\
(\mathrm{m})\end{array}$ & $\begin{array}{c}\text { Avg. fuel } \\
\text { load } \\
\left(\text { ton.ha }^{-1}\right)\end{array}$ & $\begin{array}{c}\text { Avg. fuel } \\
\text { moisture }(\%)\end{array}$ & Fuel species \\
\hline 853 & 16 & 67 & 0.31 & 32.50 & $\begin{array}{c}\text { Live: } 46.6 \\
\text { Dead: } 9.0\end{array}$ & $\begin{array}{c}\text { Erica umbellata, Erica } \\
\text { australis, Ulex minor, } \\
\text { Chamaespartium } \\
\text { tridentatum }\end{array}$ \\
\hline
\end{tabular}

Average meteorological data acquired during the burn are shown in Table 2.

Table 2. Average meteorological data observed from 10:00 to 10:50.

\begin{tabular}{cccc}
\hline $\begin{array}{c}\text { Wind velocity } \\
\left(\mathrm{m} . \mathrm{s}^{-1}\right)\end{array}$ & $\begin{array}{c}\text { Wind direction } \\
(-)\end{array}$ & $\begin{array}{c}\text { Air temperature } \\
\left({ }^{\circ} \mathrm{C}\right)\end{array}$ & $\begin{array}{c}\text { Air humidity } \\
(\%)\end{array}$ \\
\hline 3.1 & East (uphill) & 12.8 & 45.6 \\
\hline
\end{tabular}


As shown in Figure 1, no significant variation of wind velocity and direction was reported in this period.

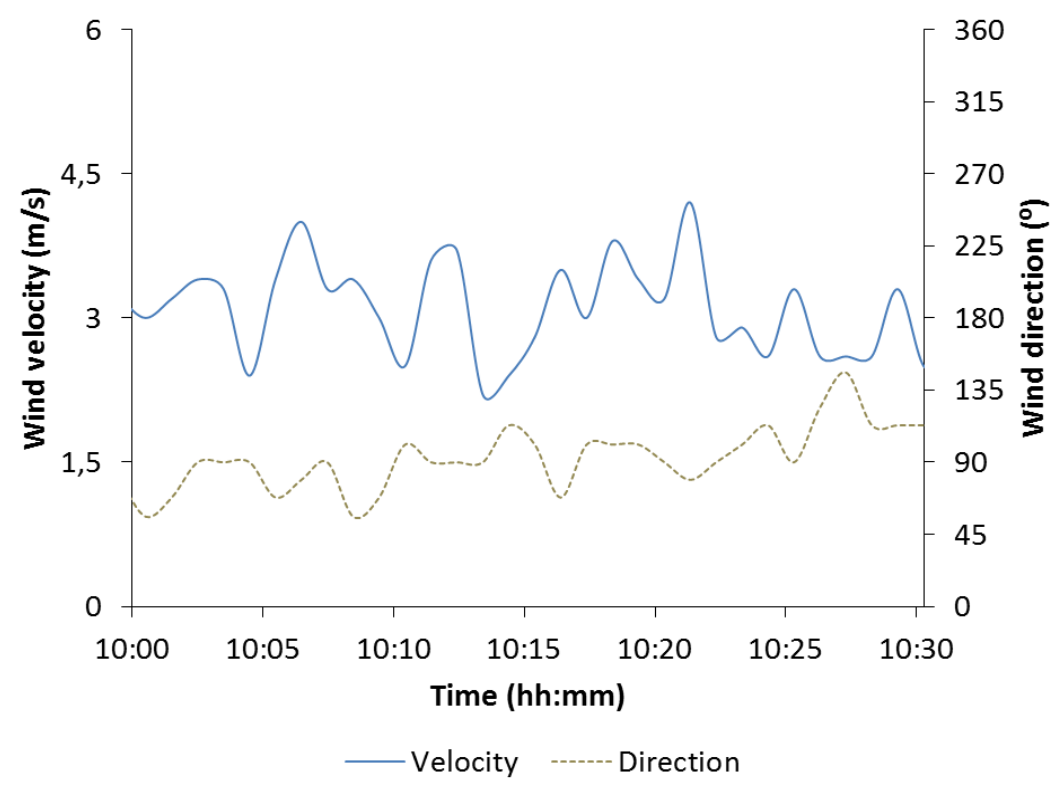

Figure 1. Meteorological data measured during the experiment.

The procedure for the fire ignition is presented in Table 3.

Table 3. Fire ignition ( $\Delta t$ indicates time after ignition).

\begin{tabular}{|c|c|c|c|}
\hline $\begin{array}{l}\text { Fire ignition } \\
\text { (hh:mm) }\end{array}$ & $\begin{array}{l}\text { End of flaming } \\
\text { stage (hh:mm) }\end{array}$ & $\begin{array}{c}\text { End of } \\
\text { smouldering } \\
\text { stage (hh:mm) }\end{array}$ & Fire ignition description \\
\hline $\begin{array}{c}10: 00 \\
(\Delta t=0 \mathrm{~min})\end{array}$ & $\begin{array}{c}10: 30 \\
(\Delta t=30 \mathrm{~min})\end{array}$ & $\begin{array}{c}10: 50 \\
(\Delta t=50 \mathrm{~min})\end{array}$ & $\begin{array}{l}\Delta \mathrm{t}=0 \mathrm{~min} \text { : Linear ignition along the top (West) } \\
\text { boundary of the plot starting at the right } \\
\text { (North) side; } \\
\Delta \mathrm{t}=7 \text { min: Linear ignition parallel to the initial } \\
\text { one and starting at the left (South) side; } \\
\Delta \mathrm{t}=13 \text { min: Downhill linear ignition along the } \\
\text { right (North) boundary of the plot; } \\
\Delta \mathrm{t}=16 \text { min: Downhill linear ignition along the } \\
\text { left (South) boundary of the plot; } \\
\Delta \mathrm{t}=19 \text { min: Linear ignition along the bottom } \\
\text { (East) boundary of the plot starting at the right } \\
\text { (North) side and covering the first } 1 / 3 \text { of the } \\
\text { total width; } \\
\Delta \mathrm{t}=27 \text { min: Linear ignition along the bottom } \\
\text { (East) boundary of the plot, covering the } \\
\text { remaining } 2 / 3 \text { of the total width. }\end{array}$ \\
\hline
\end{tabular}


A snapshot of the plot burning is shown in Figure 2. The effect of the uphill wind is evident in the behaviour of the smoke plume. Also, the effect of the decreased heat release in the smouldering stage is evident in the diminishing of the plume rise in image (d).

(a)

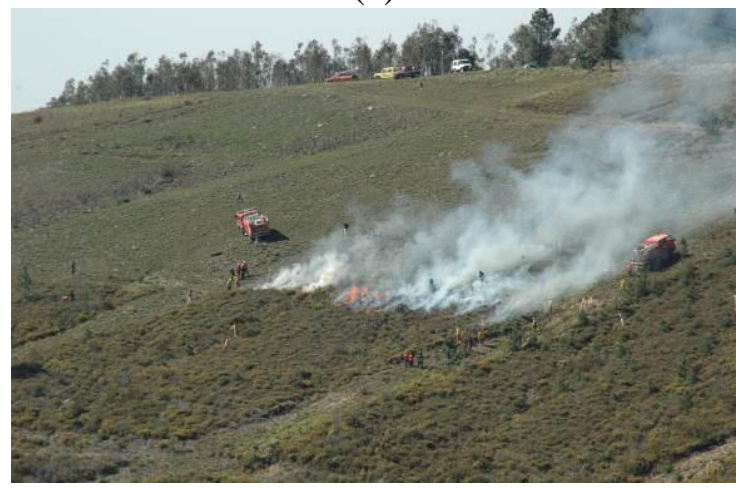

(c)

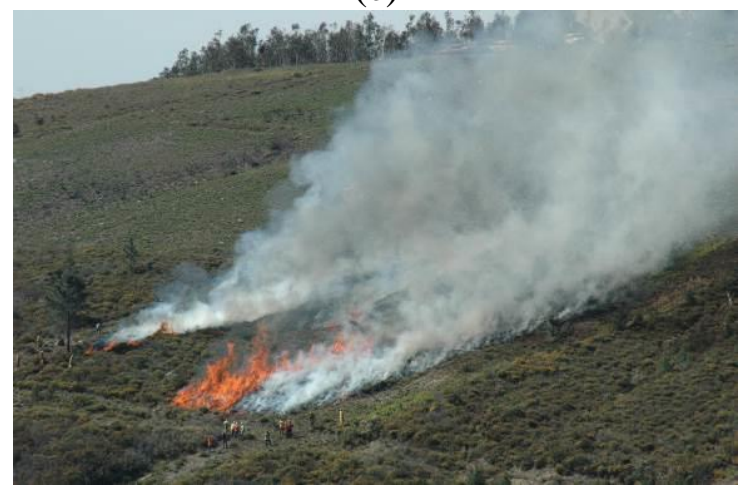

(b)

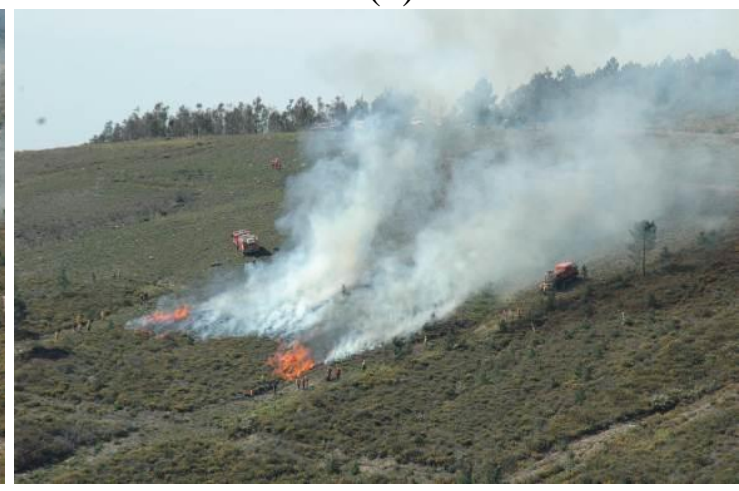

(d)

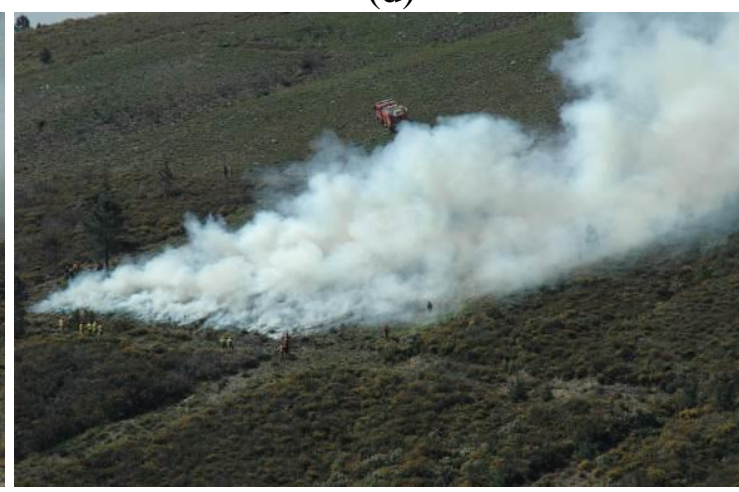

Figure 2. Sequence of photos showing the plot burning at: (a) 10:05 ( $\Delta t=5 \mathrm{~min}$ ), (b) 10:14 ( $\Delta t=14 \mathrm{~min}$ ), (c) 10:22 $(\Delta t=22 \mathrm{~min}$ ), and (d) 10:32 ( $\Delta t=32 \mathrm{~min}$, corresponding to the start of the smouldering stage).

The layout of the sensor grid is schematically shown in Figure 3. Ten in-continuum air quality monitoring sensors were distributed at intervals of $5 \mathrm{~m}$ along the top boundary of the plot. The two lines of sensors are, respectively, at $5 \mathrm{~m}$ ( 8 sensors) and $10 \mathrm{~m}$ ( 2 sensors) from the top (West) boundary of the plot. This grid was defined according to the prevailing winds during the burns, with the objective of capturing the smoke plume. 


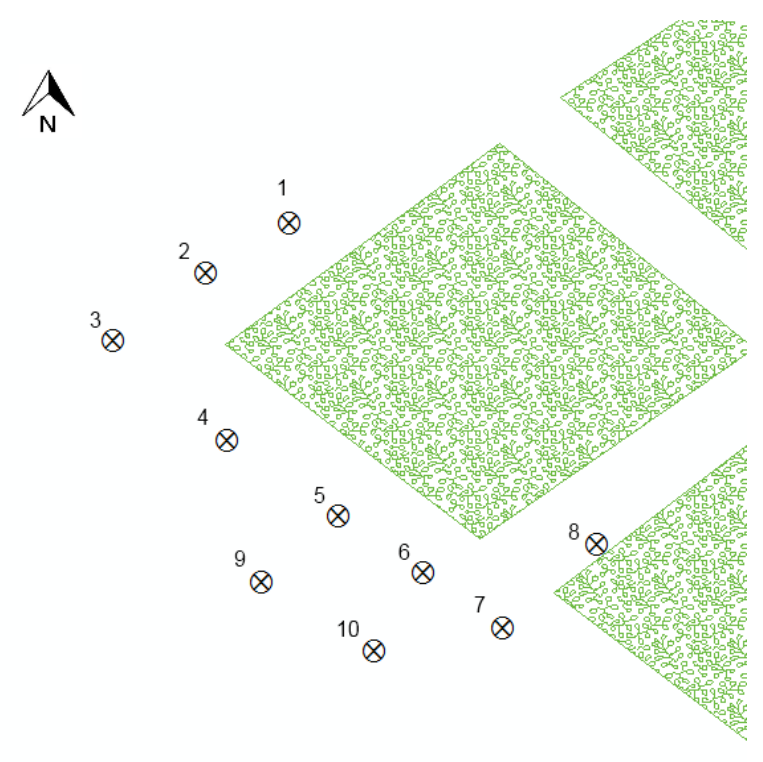

Figure 3. Sensors grid layout.

The equipment used for the measurement of the concentration of particles with an equivalent aerodynamic diameter smaller than $2.5 \mu \mathrm{m}$ (PM2.5) was a SidePack AM510 $\left(\mathrm{TSI}^{\mathrm{TM}}\right.$ ) (for more details on the sensors see Miranda et al. [2010]). Each sensor was fixed to a mast at a height of approximately $1.7 \mathrm{~m}$ above ground, as can be seen in Figure 4.

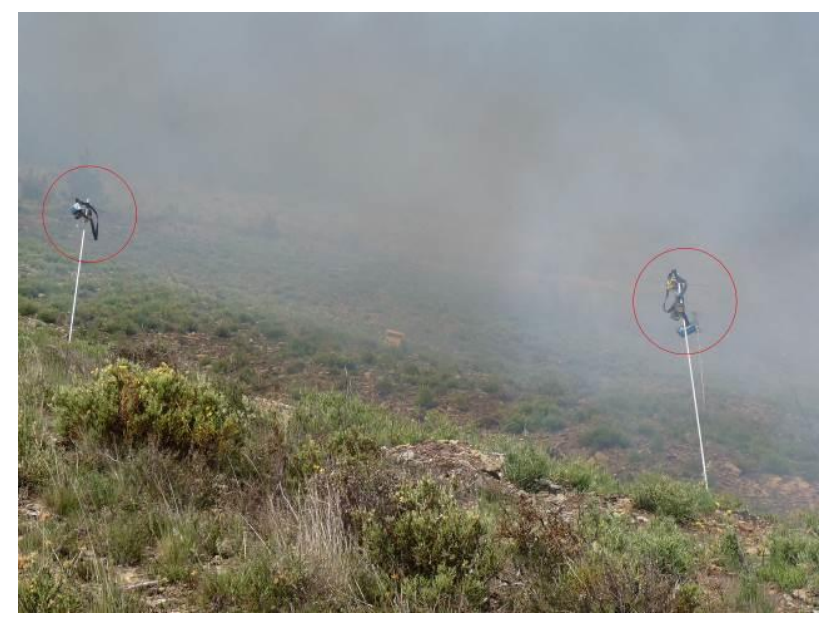

Figure 4. PM2.5 monitoring sensors indicated by the circles.

\section{Experimental data analysis}

Figure 5 shows the PM2.5 concentration acquired in each sensor normalized by the global average for all sensors. 


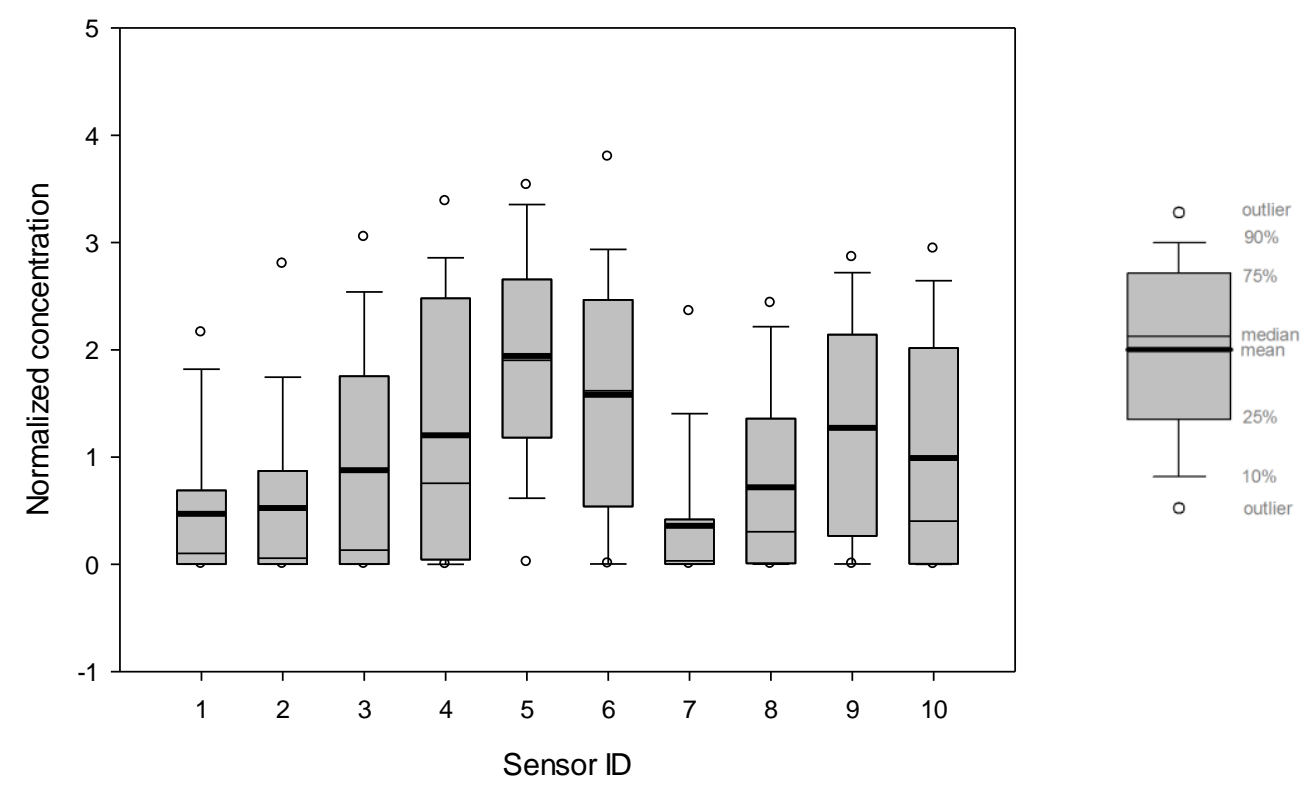

Figure 5. Box plots of normalized 1 min averaged PM2.5 concentration per sensor.

Figure 5 shows a clear discrepancy on the magnitude of the concentrations attained, with sensor 5 hitting an average concentration 5.4 times higher than sensor 7, and 1.7 times higher in the case of peak values, despite the short distance $(10 \mathrm{~m})$ between these sensors. Standard deviation is also dependent on sensor location, ranging from 0.6 (sensor 7) to 1.2 (sensor 4). These conclusions are in agreement with previous measurements carried out by the authors [Miranda et al., 2010] in similar plots but in which the measuring equipment was used by firefighters (consequently, not representing a specific spot but a given job in the crew).

For an additional understanding of the time evolution of PM2.5 levels, 1 minute averaged normalized values are shown in Figure 6.
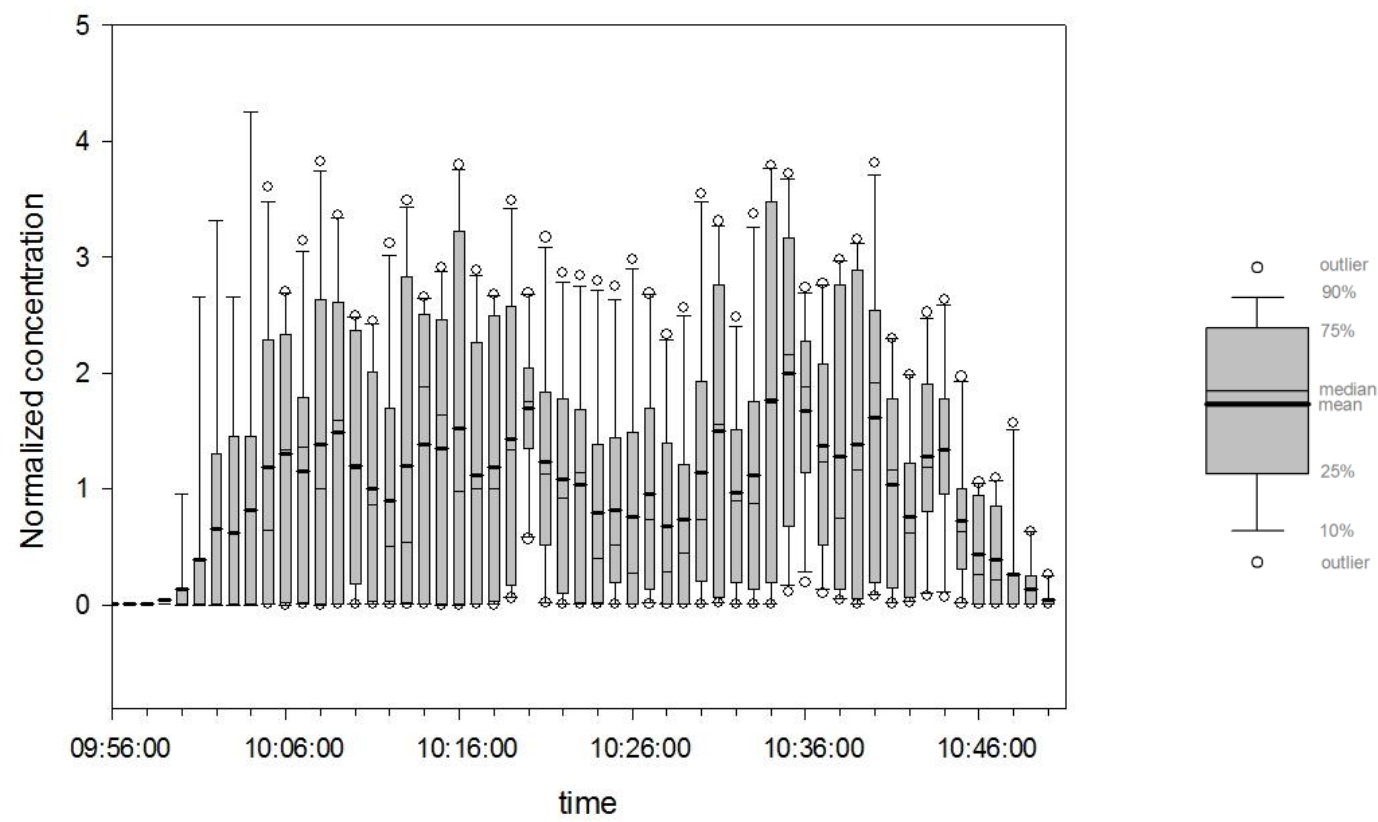

Figure 6. Box plots of normalized 1 min averaged PM2.5 concentration per sensor (a) and per minute (b). 
The decrease of concentration around 10:26 shown in Figure 6 corresponds to the end of the flaming stage (at 10:30), thus revealing two distinct fire stages. It is possible to conclude that the PM2.5 levels captured during the first 30 minutes are resulting from a combination of both flaming and smouldering emissions, while the second peak in concentration (around 10:36) is exclusively caused by smouldering emissions, showing the significant contribution of the smouldering phase to the emission of fine particles, again in the agreement with the previous campaign by Miranda et al. [2010]. In fact, the (1 minute) average concentration values are higher in this second stage, which is also a consequence of the weakened plume rise (as already observed in the analysis of Figure 2).

Additionally, it is worth to observe in Figure 6 that in the flaming stage a dip in PM2.5 concentration was observed for approximately 6 minutes, starting at 10:10. This effect is not explained by the analysis of smoke plume dynamics in video recordings (at least from the observation point), in which a significant (horizontal or vertical) deviation of the plume was not observed, neither a decrease on fire intensity.

\section{Conclusions}

It is generally accepted that firefighters are potentially exposed to critical levels of air pollution during fire suppression activities (both in direct combat and mop-up), but the concentrations attained during these operations are still scarcely quantified. The goal of this work is to give a better understanding of the spatiotemporal dynamics of the smoke plume, and resulting PM2.5 levels, in the close proximity of a fire.

The results presented in this work highlight the fact that the concentration of fine particles in the atmosphere close to the fireline is extremely dynamic, with differences between sensors that go up to $540 \%$ in terms of average concentrations and $170 \%$ in peak values. This is particularly relevant taking into account that these differences were registered in sensors at a distance of $10 \mathrm{~m}$. This conclusion suggests that in a single fire crew considerable differences in the exposure of its members can occur depending on their task/position in relation to the fire front.

Data analysis suggests also that the visual estimate of fire safety conditions can be misleading, as concluded from the comparison between monitored PM2.5 levels and video footage, as a consequence of e.g. reduced visibility. In wildfire suppression operations the safety of the involved personnel should rely also on the use of personal exposure monitoring equipment for the prevention of potentially critical exposure.

In agreement with previous field measurements [Miranda et al., 2010] the smouldering stage can be critical to the security of firefighters in the terrain, because of the higher emission of fine particles (when compared to the flaming phase) and the 'immersion' of firefighters in smoke when carrying out mopping operations (due to the decreased fire intensity).

\section{Acknowledgements}

This work was supported by European Funds through COMPETE and by National Funds through the Portuguese Science Foundation (FCT) within projects PEst-C/MAR/LA0017/2013, FUMEXP (PTDC/AMB/66707/2006) and VitalResponder2 (PTDC/EEI-ELC/2760/2012), and the Post-Doc grants of J.H. Amorim (SFRH/BPD/48121/2008) and J. Valente (SFRH/BPD/78933/2011).

\section{References}

Dost FN, 1991. Acute toxicology of components of vegetation smoke. Rev Environ Contam Toxicol 119, 1-46. 
IARC, 2010a. International Agency for Research on Cancer. IARC Monographs on the Evaluation of Carcinogenic Risks to Humans. Volume 98 - Painting, Firefighting, and Shiftwork. Lyon, France. $804 \mathrm{p}$.

IARC, 2010b. International Agency for Research on Cancer. IARC Monographs on the Evaluation of Carcinogenic Risks to Humans. Volume 92 - Some Non-Heterocyclic Polycyclic Aromatic Hydrocarbons and Some Related Exposures. Lyon, France. 868 p.

LeMasters GK, Genaidy AM, Succop P, Deddens J, Sobeih T, Barriera-Viruet H, Dunning K \& Lockey J, 2006. Cancer risk among firefighters: a review and meta-analysis of 32 studies. J Occup Environ Med 48(11), 1189-1202.

Materna BL, Koshland CP \& Harrison RJ, 1993. Carbon monoxide exposure in wildland firefighting: a comparison of monitoring methods. Appl Occup Environ Hyg 8(5), 479-87.

McMahon CK \& Bush PB, 1992. Forest worker exposure to airborne herbicide residues in smoke from prescribed fires in the southern United-States. Am Ind Hyg Assoc J 53(4), 265-72.

Miranda A.I., Martins V., Cascão P., Amorim J.H., Valente J., Borrego C., Ferreira A.J., Cordeiro C.R., Viegas D.X. \& Ottmar R., 2012. Wildland smoke exposure values and exhaled breath indicators on firefighters. J Toxicol Env Heal A 75(13-15), 831-843.

Miranda A.I., Martins V., Cascão P., Amorim J.H., Valente J., Tavares R., Borrego C., Tchepel O., Ferreira A.J., Cordeiro C.R., Viegas D.X., Ribeiro L.M. \& Pita L.P., 2010. Monitoring of firefighters exposure to smoke during fire experiments in Portugal. Environ Int 36, 736-745.

Naeher LP, Brauer M, Lipsett M, Zelikoff JT, Simpson CD, Koenig JQ \& Smith KR, 2007. Woodsmoke health effects: a review. Inhalat Toxicol 19, 67-106.

Reinhardt T.E. \& Ottmar R.D., 2004. Baseline measurements of smoke exposure among wildland firefighters. J Occup Environ Hyg. 1, 593-606.

Reinhardt TE \& Ottmar RD, 2000. Smoke exposure at western wildfires. USDA Forest Service Pacific Northwest Research Station Research Paper; 525 p.

Reinhardt TE, Ottmar RD \& Hanneman A, 2000. Smoke exposure among firefighters at prescribed burns in the Pacific Northwest. USDA Forest Service Pacific Northwest Research Station Research Paper 526, 1-45.

Reisen F. \& Brown S.K., 2009. Australian firefighters' exposure to air toxics during bushfire burns of autumn 2005 and 2006. Environ Int 35, 342-52.

Reisen F., Hansen D. \& Meyer C.P., 2011. Exposure to bushfire smoke during prescribed burns and wildfires: firefighters' exposure risks and options. Environ Int 37, 314-321.

Rothman N, Ford D.P., Baser M.E., Hansen J.A., O'Toole T., Tockman M.S. \& Strickland PT, 1991. Pulmonary function and respiratory symptoms in wildland firefighters. J Occup Med 33(11), 11631169.

Schwela D, 2001. Fire disasters: the WHO-UNEP-WMO health guidelines for vegetation fire events. Ann Burns Fire Disasters 13, 178-179.

Youakim S, 2006. Risk of cancer among firefighters: a quantitative review of selected malignancies. Arch Environ Occup Health 61(5), 223-231. 